\title{
不動産法の最前線
}

\section{代償分割における代償債務の 課税上の取扱い}

Masaki IGAWA : Meijo University

伊川 正樹*

\section{Iはじめに}

遺産分割の方法として, 現物分割, 換価分割, 代償分割がある。このうち換価分割とは, 共同相 続人が遺産を未分割の状態で換価し，その代金を 分割する遺産分割の方法をいう（家手法194条, 相基通19の 2-8 (注))。これに対して代償分割と は, 共同相続人のうちの 1 人または数人が相続に より取得した財産の現物を取得し, その現物を取 得した者が他の共同相続人に対して債務を負担す る方法によって行う遺産分割の方法をいう（家手 法195条，相基通19の 2-8 (注))。

これらの遺産の分割方法は, 「遺産に属する物 又は権利の種類及び性質, 各相続人の年齢, 職業, 心身の状態及び生活の状況その他一切の事情を考 慮して」(民法906条) 行われる限り, 遺産分割協 議ないし審判（民法907条）において採りうる選 択肢として優劣はないものといえる1。それにも かかわらず，遺産分割の方法が換価分割なのか, 代償分割なのかによって, 課税上の取扱い, とり わけ譲渡所得課税に相違が表れる。

こうした課税上の取扱いは, 相続開始時におけ る相続税と譲渡所得税の関係をどのようにとらえ,
それをいかに調整するかという問題に帰着する2。 そこで, 代償分割における代償債務の課税上の取 扱い3という問題につき，これを取得費として控 除することができるかについて考察する4。加え て, 立法論としての解決の可能性についても提示 する。

\section{II 現行法上の取扱い}

\section{1 代償分割に係る相続税の課税価格}

代償分割によって遺産分割が行われた場合, 代 償債務を負担することになった相続人とそれを受 け取った相続人に対する相続税の課税価格は, 次 のように算定される（相基通11の 2-9）。

・代償財産の交付をした者：相続または遺贈に より取得した財産の価額－交付する代償財産 の価額

・代償財産の交付を受けた者：相続または遺贈 により取得した財産の価額＋交付を受けた代 償財産の価額

このように，代償債務を負担して相続財産を取 得した相続人は，交付した代償財産の価格を控除 して相続税の課税価格が算定され, 他方, 代償財 産の交付を受けた相続人は, 当該交付を受けた財

伊川 正樹* (いがわ まさき) 正会員・名城大学法学部教授

1 代表的な民法の基本書においても，両者は遺産分割の方法として並列的に紹介されるのみで，特段の扱いはされていは ない。参照, 内田貴『民法IV [補訂版]』422頁, 428頁 (東京大学出版会, 2004年), 前田陽一 = 本山敦 = 浦野由紀子『民 法IV 親族・相続』307頁 (有斐閣, 2010年) [前田執筆] 等参照。

2 拙稿「譲渡所得税と相続税との調整」税法学 572 号 3 頁 (2014年)。

3 三木義一 $=$ 関根稔 $=$ 山名隆男 $=$ 占部裕典『実務家のための税務相談（民法編）第 2 版』327頁以下（有斐閣，2006年）, 三木義一 $=$ 末崎衛『相続・贈与と税〔第 2 版〕』68頁以下 (信山社, 2013年), 東京弁護士会編『新訂第七版 法律家の ための税法 [民法編]』374頁 (第一法規, 2014年), 西山恭博「相続時の分割方法と譲渡所得の考え方の検討一代償分割 における現状の考え方を中心として一」創価法学44巻 2 号85頁以下 (2014年) 参照。

4 本稿では紙幅の関係上,「代償金を取得費に含めるべきか」という点について肯定的な立場から, その方法論について考 察する。この点についての考察は, 別稿を予定している。 
産の価格を加算した合計額が相続税の課税価格と されている。

\section{2 代償分割に係る所得税の取扱い}

代償分割において交付される代償財産は，金銭 以外の現物の場合（現物交付代償分割）と金銭に よる場合 (代償金) とがある。所得税の取扱いは それぞれの場合によって異なる。

（1）代償財産として金銭以外の資産を交付した 相続人（現物交付代償分割）

代償分割として相続人が所有する資産を交付し たときは，履行時の時価により当該資産を譲渡し たものとして, 譲渡所得課税が行われる（所基通 33-1の 5 )。すなわち, 代償財産を交付した相続 人は, 自己の保有する資産を他の相続人に対して 譲渡したものと扱われ, 当該譲渡時における時価 相当額の総収入金額があったものとして，譲渡所 得に対する課税が行われることになる（所税33条 1 項, 3 項)。

（2）代償財産として金銭の交付をして相続財産 を取得した相続人（代償金の支払い）

他の相続人に代償金を交付して相続財産を取得 した場合，当該相続人は，金銭の譲渡であるため 譲渡所得課税が行われないことは当然であるが (所税 33 条 1 項参照 $)^{5}$, 他方で, 当該代償金の金 額を相続により取得した資産の取得費に算入する ことができない（所基通38-7(1)）。

(3) 代償財産を取得した相続人

代償分割として代償財産を取得した相続人は, その代償財産が現物か代償金かを問わず，履行時 の時価によって取得したこととなる（所基通 38-7(2))。ただし，これは上記のように相続税の 課税価格に加算されることから相続税の課税対象
となり, 所得税法上は, 取得した現物代償財産の 取得費を構成するという意味を持つことになる。

\section{3 代償金 ${ }^{6}$ 取得費該当性}

\section{(1) 最高裁の解釈}

上記 $2(2)$ でみたように，他の相続人に交付した 代償金は，当該相続人が相続により取得した資産 の取得費に算入することができないと解されてい る。しかし一般的な感覚からすれば, 代償金を他 の相続人に支払って相続財産を取得した相続人か らすれば，代償金は当該財産の取得に要した費用 （所税38条 1 項）に当たると考えるのが通常であ ろう。

この点が争われた裁判例では, 最高裁は次のよ うに判示し，この点を否定している（最判平成 6 年 9 月 13 日判時 1513 号 97 頁 ${ }^{7}$ 。

「相続財産は，共同相続人間で遺産分割協議 がされるまでの間は全相続人の共有に属する が，いったん遺産分割協議がされると遺産分 割の効果は相続開始の時にさかのぼりその時 点で遺産を取得したことになる。したがって， 相続人の一人が遺産分割協議に従い他の相続 人に対し代償としての金銭を交付して遺産全 部を自己の所有にした場合は, 結局, 同人が 右遺産を相続開始の時に単独相続したことに なるのであり, 共有の遺産につき他の相続人 である共有者からその共有持分の譲渡を受け てこれを取得したことになるものではない。 そうすると, 本件不動産は, 上告人が所得税 法60条 1 項 1 号の『相続』によって取得した 財産に該当するというべきである。したがっ て，上告人がその後にこれを他に売却したと きの譲渡所得の計算に当たっては，相続前か

\footnotetext{
5 譲渡所得に対する課税の趣旨である増加益清算説からすれば, 譲渡所得の課税対象となる「資産」(所税 33 条 1 項）とは, 保有期間中に価值が増減し，譲渡時にそれを清算して課税することができる性質のものをいう。したがって，金銭は譲 渡所得課税における「資産」には当たらないものと解される。参照, 拙稿「譲渡所得の起因となる『資産』概念一増加 益清算課税説の再考一」名城法学 57 巻 1 - 2 合併号 141 頁以下 (2007年), 拙稿「譲渡所得課税に扔ける『資産の譲渡』」 税法学561号 3 頁以下 (2009年)。金銭債権から生じる利益は利子に当たることも，こうした解釈の根拠となる。

6 これまで述べてきたように，代償財産として交付する財産は金銭に限らないが，ここでみる裁判例は代償金に関するも のであるため，これ以降は便宜上，すべて代償金に限って論じていく。ただし，現物交付の場合も問題は同様である。

7 同判決に関する評釈等として, 田中治「判批」租税法研究24号196頁（1996年）, 大崎満「判批」ジュリ1084号116頁（1996 年), 石原直樹「判批」判夕913号 (平成 7 年主要民事判例解説) 282頁 (1996年), 無署名「判批」金商1411号40頁 (1995 年) 参照。
} 
ら引き続き所有していたものとして取得費を 考えることになるから, 上告人が代償として 他の相続人に交付した金銭及びその交付のた め銀行から借入れた借入金の利息相当額を右 相続財産の取得費に算入することはできな い。」(下線部，筆者)

このように最高裁は, 遺産分割の遡及効（民法 909条本文）を根拠として，代償金の取得費該当 性を否定している。この判断をめぐって，民事実 体法体系および本件代償金の性質から判断してこ うした解釈を妥当なものと評価する論者もいる が8, 批判的な見解も多く存在する。たとえば, 民法理論でさえ貫徹されていない遡及効を, 譲渡 所得課税の場面でことさらに強調することに対す る疑問 ${ }^{9}$ や，代償金の支払は対価性（相続財産の 持分の譲渡代金たる性格）をもつといえるため, 取得費に当たるとする見解 ${ }^{10}$ などがある。

(2) 相続税と譲渡所得に対する課税との関係

代償金の取得費該当性というこの問題は，相続 税の負担と譲渡所得の課税との関係が深く関わっ ており, 最高裁はこの点に配慮をしつつ, 現行所 得税法上の譲渡所得に対する課税の趣旨を踏まえ て解釈したものと思われる。

すなわち，仮に代償金の支払いを相続財産の持 分の譲渡代金ととらえて取得費として控除を認め るとなると, 被相続人の取得時から相続開始時点 までに生じた值上り益のうち, 代償金相当部分に は譲渡所得課税を行うことができないことになる。 現行所得税法は, 59条 1 項所定の場合を除き, 無 償譲渡については60条 1 項が適用され, 譲渡の時 点では值上がり益には課税せず，課税を繰り延べ るという措置を講じている。こうしたしくみは, 譲渡所得の全額課税と譲渡損失の税額控除を目指 したシャウプ勧告に由来する。現行法上は上記の ように, 譲渡の時点で増加益を清算するか, 課税
を繰り延べて後に実現した時点で課税するという しくみを採用しており，発生した值上り益の課税 に漏れがないような制度を採用しているのである。 したがって，代償金を取得費として控除を認める ことにより，その部分についての課税漏れを生じ させることは，こうした課税の趣旨に反すること になる。

また，代償金を取得費に含めないという解釈は， 代償金受領者に対する相続税と譲渡所得税の負担 を考慮したものと考えられる。すなわち，代償金 を代償金支払者の取得費に含めるという解釈を採 る場合，代償金受領者は，相続によって取得した 自己の相続分を代償金支払者に対して譲渡し，そ の対価として代償金を受領したと考えることにな る。そうすると代償金受領者は, 相続によって取 得した財産につき相続税が課され，さらにそれを 代償金支払者に譲渡して対価として得た代償金に

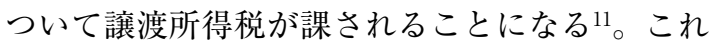
については相続税額の取得費加算の特例（措法39 条）があるが，相続開始から 3 年以内という制限 があることからこの特例を適用できない場合があ りうるため，代償金受領者にとって税負担が重く なるとともに，「二重課税」のような事態を招く 可能性がある。上記最高裁および所得税基本通達 の解釈は，こうした点を考慮したものとも考えら れる。

もっとも，譲渡所得に課税漏れを生じさせるか どうかというのは立法政策上の問題であり, 法改 正によってこのしくみを変更することは可能であ る ${ }^{12}$ 。では，代償金を取得費に含めるという方向 での解決を探るとなると，どのような方法があり うるだろうか。次章でそのいくつかについて検討 してみよう。

\footnotetext{
8 大崎 $\cdot$ 前掲注 $(7) 118$ 頁。

9 三木 $=$ 末崎 $\cdot$ 前掲注 $(3) 74$ 頁。

10 田中・前掲注 $(7) 197$ 頁。

11 金子宏「譲渡所得における『取得費』の意義一若干の裁判例を素材にして—」同『課税単位及び譲渡所得の研究』250頁 以下，283頁 (有斐閣，1996年) [初出1981年]，三木 = 末崎・前掲注(3)75頁。

12 立法的解決を指摘するものとして，金子・前掲注（11）285頁。
} 


\section{III 解決方法の検討}

\section{1 解釈論的解決方法}

（1）代償金に対価性があるとする見解

代償金を支払って相続財産を取得した者につき， 当該代償金の額をその者の取得費に含めるという 解釈を行う場合, 代償金の受領者は相続によって 取得した相続財産の持分を譲渡した対価として代 償金を受領したと解することになる ${ }^{13}$ 。代償金の 性格を相続財産の持分の譲渡代金と解することに より，このような解釈が可能になると考えられる。

\section{（2）取得費の性質に基づく見解}

取得費の性質に基づく解釈もありうる。すなわ ち，譲渡所得の金額の計算上，控除が認められる 取得費（所税 33 条 3 項, 38 条 1 項）には, いわゆ る付随費用が含まれることが判例上確立してい $ろ^{14}$ 。この付随費用は, 現実の取得を前提とし, 支出することが社会的に承認されている支出をい うとの解釈が示されている15。また, 同様に控除 が認められている譲渡費用（所税 33 条 3 項）につ いては,「一般的, 抽象的に当該資産を譲渡する ために当該費用が必要であったかどうかによって 判断するのではなく, 現実に行われた資産の讓渡 を前提として，客観的に見てその譲渡を実現する ために当該費用が必要であったかどうかによって 判断すべき」との基準が示されている16。

こうした一連の判例からいえることは, 譲渡所 得金額の計算における控除項目は, 「現実の取得 ないし譲渡にとって必要かどうか」という視点が 重要であることである。判例・通説は, 譲渡所得 の課税の趣旨を増加益清算説によって説明し,「譲 渡所得の発生には, 必ずしも当該資産の譲渡が有 償であることを要しない」と述べる17。ただし， 同説の内容は, (1)保有期間中の増加益が譲渡所得 であること，(2)その課税のタイミングは譲渡時で
あることを示す,「課税の趣旨」に関するもので ある。すなわち, 所得税法が実現主義（所税 36 条）を採用している以上，発生段階での未実現利 益には課税せず，実現した所得にのみ課税するこ とから（所税59条 1 項が定めるみなし譲渡の場合 は除く), 増加益清算説のみに基づいて現実に課 税をすることができず，実現した収入金額を前提 として所得金額を算定する必要がある。そのため には，「現実の取得」や「現実の譲渡」を前提と しなければならない。

上記の取得費, 譲渡費用および付随費用の判断 基準に関する判例もかかる前提に立って解釈した と解され，控除が認められるかどうかは「現実の 取得ないし譲渡にとって必要かどうか」という基 準で判断する必要がある。このように解せば, 代 償金を支払って相続財産を取得した相続人は，そ の支払いを行わなければ「現実に」当該財産を取 得したということはできない。相続によって相続 財産は共同相続人間の共有に属し, 遺産分割協議 はまさに分割行為であって取得行為ではないとい うのが民法上の確立した解釈である。だが，未分 割の状態で自己の持分を自由に譲渡することはで きず，遺産分割協議の成立によってはじめて自己 の持分が現実に確定するのである。そして代償金 の支払いは，この「現実の取得」にとって必要な ものであることから, 譲渡所得金額の計算上, 取 得費に該当すると解することは可能である。民法 上は相続によって財産を取得したといいえても， 譲渡所得課税の場面での判断基準は「現実の取 得」であることから, 代償金を取得費あるいは付 随費用に含めるという解釈は可能であるというべ きである18。

\section{2 立法論的解決方法}

\section{(1) 相続税と譲渡所得税との調整}

相続によって財産を取得した場合，当該相続人

\footnotetext{
${ }^{13}$ 田中・前揭注(7)197頁。

14 最判平成 4 年 7 月 14 日民集 46 巻 5 号 492 頁, 最判平成 17 年 2 月 1 日訟月 52 巻 3 号 1034 頁。

15 東京高裁平成 23 年 4 月 14 日税資 261 号順号 11668 。参照, 拙稿「譲渡所得課税における取得費および付随費用ならびに譲 渡費用」立命館法学352号 1 頁以下 (2014年)。

16 最判平成18年 4 月 20 日判時1933号76頁。

17 最判昭和 47 年 12 月 26 日民集 26 巻 10 号 2083 頁，最判昭和 50 年 5 月 27 日民集 29 巻 5 号 641 頁参照。

18 拙稿・前揭注（16）28頁。
} 
には相続税が課される。そして当該相続財産に, 被相続人の保有期間中に值上り益が生じていた場 合, 現行法上, それは相続時点では譲渡所得とし て課税されないことを原則とし，相続人に対する 取得価額の引継ぎという形で課税が繰り延べられ ることとされている (所税60条 1 項 1 号)。

このようなしくみを前提とすれば，相続人は， 相続財産を取得したことによって相続税が課され， その財産に含まれている值上がり益について，後 に譲渡した際に譲渡所得税が課されることとなり， これは「二重課税」に当たるのではないかという 疑義が生じる。

しかし, 現行法の解釈によればこれは二重課税 には当たらず, むしろ現行所得税法はこうした 「両面課税」を予定しているとして, 両者の調整 は不要であると解されている（ただし租税特別措 置法39条は，相続税額を取得費に加算するという 形での一定の調整を図っている $)^{19}$ 。

もっとも，これは解釈論としての結論であって， 立法論として両者の調整が不要ということまでを 意味するものではない。この問題について立法的 に解決するには，(1)相続税のレベルでの調整（課 税方式の変更を含む) と(2)譲渡所得税のレベルで の調整がありうる ${ }^{20}$ 。これにはさまざまなバリ エーションがありうるが, 代償分割による相続の 場面における調整方法としては，次のようなもの がある。

(2) 調整方法

(a) 相続時に被相続人に対してみなし譲渡所得 課税を行い，その金額を相続税から債務控除する 方法 ${ }^{21}$

この方法によれば，代償分割の基礎にある法律 関係は持分権の有償譲渡にほかならないと考えて
代償金を取得費に算入しても，あるいは代償分割 を親族間の取引と考えて代償金を取得費に算入し なくても，代償金支払者と代償金受領者が支払わ なければならない譲渡所得税と相続税の額は同一 となるとされている。

（b）相続時（代償分割時）に代償金受領者に対 して代償金部分について譲渡所得課税を行い, そ の金額を相続税の課税対象から除外する方法22

この方法によれば，代償金受領者が相続時に， 受領した代償金の部分について代償金受領者の譲 渡所得税の申告を行い, その分の所得税額は, 相 続税の課税対象から除外することになる。

\section{N おわりに}

代償債務（代償金）の取扱いをめぐり，相続税 と譲渡所得税の調整という問題を検討したが，現 行法を前提とした解釈論上も取得費としての控除 は可能であるというのが本稿の結論である。ただ し, それが認められる場合でも, 代償金受領者に 対する課税をどうするかという問題は残る。

そこで，立法論による解決方法も提示したが, 上記の方法以外にも, 被相続人の保有期間中の值 上り益に対する課税は相続税のみとし，代償金支 払者は第三者への譲渡時に, 自己の保有期間中の 值上り益についてのみ譲渡所得税を負うという方 法もありうる。その際，代償金受領者に支払った 代償金は，同支払者の取得費に算入することに よって調整することになる。かかる方法は, 譲渡 所得に対する課税漏れを防ぐというシャウプ针告 以来の立法趣旨を大きく転換することになり，ま た相続税の課税方式の変更も伴うものであるが, そのような可能性も含めて検討すべきではないか と考えられる。

\footnotetext{
19 東京地判平成25年 6 月 20日TAINS Z263-12238, 控訴審・東京高判平成25年11月21日TAINS Z263-12339, 上告審 - 最決 平成27年 1 月16日TAINS Z888-1925(上告不受理)；東京地判平成25年 7 月26日TAINS Z888-1776, 控訴審 - 東京高判平 成26年 3 月27日TAINS Z888-1844，上告審・最決平成27年 1 月16日TAINS Z888-1901 (上告不受理)。

20 詳細については, 拙稿・前掲注(2)14頁以下。

21 青野勝広「代償分割における相続税と譲渡所得税の関係一『みなし譲渡所得課税と死亡時課税の組み合わせ方式』の提 案」松山大学論集 21 巻 3 号 179 頁以下, 196頁以下 (2009年)。

22 西山恭博「相続時の分割方法と譲渡所得の考え方の検討一代償分割における現状の考え方を中心として」創価法学 44 巻 2 号85頁以下, 102 104頁 (2014年)。
} 